\title{
Issues and Challenges of Joint Management Body in High-Rise Residential Facilities Management: The Developers
}

\author{
Darul Nafis Abas ${ }^{1, *}$, Rozana Zakaria ${ }^{1}$, Eeydzah Aminudin ${ }^{1}$, Nurul Asmiera Ab Lah ${ }^{1}$, \\ Nur Syafiqah Aini Mohamad Nor Sharin ${ }^{1}$, Shaza Rina Sahamir ${ }^{2}$ \\ ${ }^{1}$ School of Civil Engineering, Faculty of Engineering, Universiti Teknologi Malaysia(MARA University of Technology), Malaysia \\ ${ }^{2}$ Faculty of Architecture Planning and Surveying, Universiti Teknologi MARA (MARA University of Technology), Malaysia
}

Received January 29, 2021; Revised July 27, 2021; Accepted August 9, 2021

\section{Cite This Paper in the following Citation Styles}

(a): [1] Darul Nafis Abas, Rozana Zakaria, Eeydzah Aminudin, Nurul Asmiera Ab Lah, Nur Syafiqah Aini Mohamad Nor Sharin, Shaza Rina Sahamir, "Issues and Challenges of Joint Management Body in High-Rise Residential Facilities Management: The Developers," Civil Engineering and Architecture, Vol. 9, No. 5A, pp. 33 - 40, 2021. DOI: 10.13189/cea.2021.091304.

(b): Darul Nafis Abas, Rozana Zakaria, Eeydzah Aminudin, Nurul Asmiera Ab Lah, Nur Syafiqah Aini Mohamad Nor Sharin, Shaza Rina Sahamir (2021). Issues and Challenges of Joint Management Body in High-Rise Residential Facilities Management: The Developers. Civil Engineering and Architecture, 9(5A), 33 - 40. DOI: 10.13189/cea.2021.091304.

Copyright $\bigcirc 2021$ by authors, all rights reserved. Authors agree that this article remains permanently open access under the terms of the Creative Commons Attribution License 4.0 International License

\begin{abstract}
High demand for housing and land scarcity in the town area has increased the provision of High-rise Residential Buildings (HrRB). HrRB has different owners but shares the same land and common facilities. Its common facilities are generally prone to damages either from "wear and tear" or vandalism. Therefore, Thus, maintenance works of HrRB and its common facilities should be done properly and periodically by experienced property management company. By the introduction of new laws and implementation thereof, Joint Management Body (JMB) was established to govern the rights and obligations of three parties' i.e., purchasers, developer, and facilities manager. The residents constantly point fingers to property management if there is dissatisfaction on the damage restoration and maintenance work done. In fact, strata management issues were brought to court by owners for adjudication, such as ACN Infra Sdn Bhd $v$ Perbadanan Pengurusan Kondominium Subang Indera [2020] 3 AMR 741, duties of management corporation in repairing defects were debated. In another case of Muhamad Nazri Muhamad v. JMB Menara Rajawali \& Anor Civil Appeal No: W-02(NCVC)(A)-205710/2018, owners disputed whether the management body could charge a different rate of maintenance charges for different
\end{abstract}

properties in HrRB. Hence, this paper intends to address the issues and challenges related to property management. This research is based on a questionnaire survey from the developer's perspective. An Average Index analysis was used to rank the level of significance issues, challenges, and major roles of JMB. The key roles of developers in JMB under Strata Property Management were highlighted in order to ensure the common facilities for HrRB more manageable in its damage recovery.

Keywords Property Management, Maintenance, High-Rise Residential Building (HrRB)

\section{Introduction}

In today's world, the population of human being especially in urban areas is expeditiously increasing, causing demands for housing to rise despite vacant land deficiency. In such a desperate situation, where the world's population keep rising, land becoming deficient and expensive, developers have no others measures which lead consideration to choose High-rise Residential 
Buildings (HrRB). HrRB is a way of a settlement that secures a place for inhabitation (A. Tayyab et al., 2017). HrRB is a unique multi storey property that differs from landed property, such as bungalows and terrace houses (V. Soebiyan, et al., 2017). Thus, HrRB has mushroomed substantially as proof of its resolution in surging housing supply for everyone.

HrRB represents multi-units dwelling that shares common property or facilities provided in the HrRB area. The main feature of this property is the ownership of individual units, joint ownership of property, and a member of the corporate body responsible for managing and carrying out maintenance work on property management (A. Christudason, 2004). This makes the management of such common property complex and challenging. Therefore, a management body is needed to manage and maintain the entire HrRB as well as public area (common property) for example such as vehicle park area, passenger lift, swimming pool, landscape area, children playground, compound lighting and other open spaces in the HrRB (F U M Azian et al., 2020). Therefore, the term 'common property' that exists and becomes a term that is so meticulously with HrRB. Several definitions can be used to define 'common property, i.e. the properties or areas of the building that are used in common or shared between owners of units in the HrRB.

\section{Background of Research Development}

The idea of making HrRB as a focus of study to solve the rising of the Malaysian population's issue is very attentive. The increasing number of HrRB constructed can meet the demands for residences, which seems that the increment in the number of Malaysian will never stop; yet will continue to grow in more significant numbers. Indeed, there are many advantages of $\mathrm{HrRB}$, which attract developers to decide on the investment of $\mathrm{HrRB}$ as a solution to residence demand. In matching, it is a common acceptance of Malaysians in choosing $\mathrm{HrRB}$ as a residence either to stay alone or with their family.

P. Loftabadi (2014) stated that high-rise residential is a tall building that consumes a smaller land and a lower construction cost than other housing types, such as bungalows, single-story or double-story houses constructed in large quantities (with standards and efficient contractors). HrRB makes better use of daylight which can benefit owners of those units in the buildings through reducing electricity consumption, especially in lightings just to get some light inside the units. On the other hand, HrRB has exceptional central benefit in contrast to other types of multiple storey residences.

Nowadays, the price escalation of HrRB units makes buyers or owners of the units more demanding and fussy in terms of service quality and standard. Buyers or owners are beginning to realize that the importance of effective property management in the life of HrRB will be able to maintain the value of property and provide a high return on their investment. The continuous growth of high-rise buildings demonstrates the need for an effective property management system and ownership to inculcate a good living experience among the residents of $\mathrm{HrRB}$ in this country. However, the current practice of property management in Malaysia poses numerous problems, which affect all parties involved: the developers, property management team and owners or residents of HrRB. Owners are now knowledgeable in the proper property management practices for their unit, and therefore good management is essential and will enhance the value of the property (C.C. Cui, et al., 2003; B.G. Dale, 2003). In the past, owners might be satisfied with only the basic care-taking and cleaning service. Still, current owners demand that housing management encompasses various services, from cleaning and security services to comprehensive maintenance (J. Bloemer, et al, 1999). HrRB provides more facilities to attract buyers and makes it more complex and challenging to manage the entire buildings.

Even though $\mathrm{HrRB}$ has quite expensive fees for management and maintenance, its response to the demands of the residence is proportionally to the increasing of Malaysia's citizens. However, the issue in high-rise residential is likely not fulfilling the criteria and requirements of stakeholders. Thus, several questions need to be clarified from the developers' point of view, such as; What are the real issues and challenges in strata property management? What are the roles of developers in JMB? How to improve strata property management systems? The research essentially covers the investigation of the issues and challenges that arise, from the perspective of developers related to property management of HrRB and examines the major roles of developers in collaboration with Joint Management Body (JMB) to manage the properties in HrRB.

\section{Research Methodology}

The quantitative approach is applied to study and analyse the understanding of developer's perspective towards strata management property of high-rise building and determining which factors affecting most to the decision making for better property management. Questionnaires were distributed by hand and emailed to the respondents who are involved in construction and development in Johor Bahru and Kuala Lumpur. The questionnaire survey conducted in this study was only distributed to the construction practitioner who is attached with developers in Johor Bahru and Kuala Lumpur only. The quantitative data have provided an exploratory look at the views of a group of building professionals who are interested in or are actively practicing sustainable property management. Thirty-two (32) set of questionnaires has 
been distributed and collected from professionals who are working with the developer and been involved in the buildings development sector in Malaysia. Collected data for this study were analysed using SPSS Inc. Ver.22 and Microsoft Excel 2010 software and interpretations of results were then carried out. Average index analysis was used to utilise the significant level of rank for the respondent's perspectives. For instance, the highest average index will be ranked as the highest or first in the rank.

\section{Respondent Background}

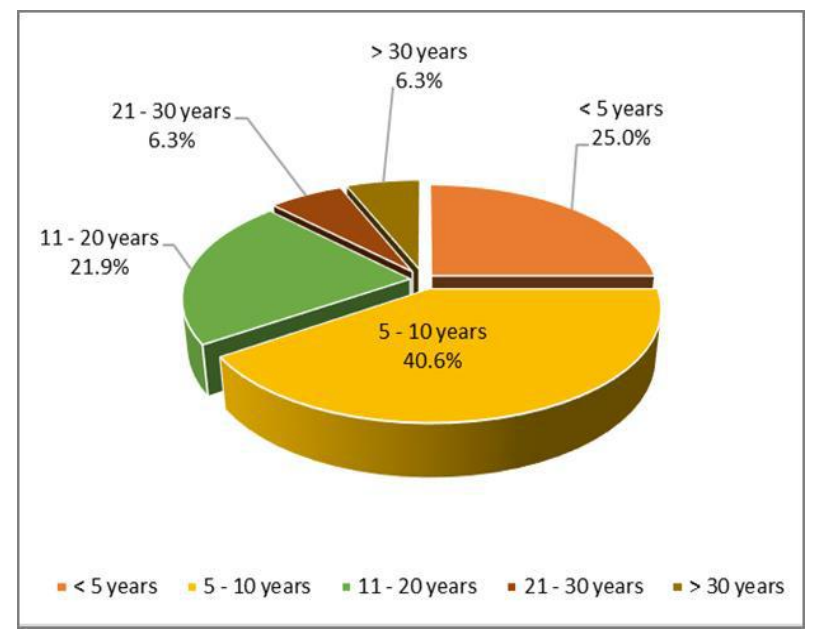

Figure 1. Respondents working experience with Developer Company

The survey questionnaire demonstrates the demographic information of the respondents which have working experiences with distributions of $6.3 \%(2)$ of respondents had more than 30 years of working experience, $6.3 \%$ (2) have between 21-30 years of working experience, meanwhile another $21.9 \%$ (7) have between 11-20 years of working experience and another $40.6 \%(13)$ have between 5-10 years of working experience. There are only $25 \%$ (5) of the respondents had less than 5 years of working experience. Thus, it can be concluded that the majority $(75 \%)$ of the respondents have more than five (5) years working with developers and have enough experience in the field of development. The results are shown in Figure 1.

\section{Issues, Challenges and Major Roles of Developers in JMB, including Improvement Strategies for Strata Property Management}

This section attempts to figure out the respondent's opinion related to issues and challenges related to Property Management, major roles of developers in the Joint Management Body (JMB) and improvement strategies for strata property management.

\subsection{Issues Related to Property Management of High-Rise Residential Buildings (HrRB)}

Table 1 shows the result of the respondent's opinions on issues related to property management of $\mathrm{HrRB}$ and the agreement percentages of respondents on the issues related to property management.

Table 1. The Level of Agreement Regarding the Issues Related to Property Management of High-rise Residential Buildings

\begin{tabular}{|c|c|c|}
\hline Issues & Average Index & Rank \\
\hline The expectation from the owner to JMB is more complex and challenging. & 7.47 & 1 \\
\hline Difficulties in getting support from owner to JMB manager. & 7.00 & 2 \\
\hline Improper planning of future maintenance of HrRB project incur higher maintenance cost. & 7.00 & 3 \\
\hline $\begin{array}{c}\text { Lack of professional practice of property management of HrRB under the management of the } \\
\text { developer resulted in higher complaints from purchasers. }\end{array}$ & 6.72 & 4 \\
\hline Loose legislation on property management and building maintenance that protect developer's interest. & 6.63 & 5 \\
\hline Property management aspects are not taken into consideration during the planning and design stage. & 6.59 & 6 \\
\hline Insufficient funds to maintain the facilities of the HrRB. & 6.53 & 7 \\
\hline Maintenance fee charged on owners is insufficient to cover maintenance cost. & 6.25 & 8 \\
\hline The developer is lack of experience in managing and maintaining high-rise residential complex. & 6.19 & 9 \\
\hline Lack of practical guidelines and a standard approach in the management and maintenance of common \\
properties involving HrRB. & 6.06 & 10 \\
\hline The developer's project team had to attend to the maintenance repair due to the inability of PM. & 5.78 & 11 \\
\hline To assign an experienced PM officer/team with good knowledge of high-rise residential buildings. & 5.63 & 12 \\
\hline Handling the PM during and after the Defect Liability Period (DLP) & 5.53 & 13 \\
\hline The involvement of the PM team during the design and construction stage. & 5.41 & 14 \\
\hline The developer has to provide a Property Management (PM) officer/team after handing over the \\
building. & 5.31 & 15 \\
\hline
\end{tabular}


Table 1 shows the results of the agreement level among the respondents toward the issues faced by the developers in relating to the property management of HrRB highlighted in the questionnaire survey. There are fifteen issues that have been raised in the questionnaire survey in order to discover the severity of the issues from the developers' perspective. The table represents the level of agreement of the developers for each highlighted issue in the questionnaire, which is arranged by ranking from the highest mean score to the lowest mean score. From the results, the three prominent issues identified by respondents are seen as the most crucial issues related to property management in $\mathrm{HrRB}$ :

a) The expectation from owner to JMB is more complex and challenging;

b) difficulties in getting support from owner to JMB manager; and

c) improperly planned future maintenance of $\mathrm{HrRB}$ project incur higher maintenance cost;

Damage/defect restoration and maintenance management efficiency can lead to maintenance management satisfaction amongst owners at a high-rise building. The management body and owners must cooperate with each other to achieve maintenance management satisfaction (J. Hussain, 1994). Nowadays, owners always point fingers to management when they are not satisfied with the maintenance work done. Residents do not realize that in order to achieve damage recovery and maintenance management satisfaction, they should play their roles in management matters. The owners should also be alert and sensitive to ongoing changes, such as their housing rules, community activities within their housing scheme, environmental conditions and maintenance service standards, especially routine maintenance works. If the owners do not give their full support and cooperation to JMB, it will lead to the failure of property management in HrRB.

The initial cost towards the building life span significantly influences developers in deciding the specification. Each building's will incur costs throughout its life cycle such as building construction costs, operational costs, maintenance service costs and other associated financial costs. The key decision is whether to spend more money initially on better alternatives in order to save money in maintaining and operating the facilities provided in HrRB. For example, the use of LED bulb, solar water heater, inverter washing machine or refrigerator, and especially inverter air conditioner in the early design stage leads to energy saving and reducing the operation and maintenance cost in the future. Most building management service provider claims that their profits are not as much as expected, and in order to adopt this integrated system, funding support is required (S.A.H. Syed et al. 2009).

\subsection{Challenges Related to Property Management of High-Rise Residential Buildings (HrRB)}

Table 2 shows the result of the respondents' opinion on the challenges related to property management of $\mathrm{HrRB}$ and the agreement percentages of respondents on the issues related to property management.

Table 2. The Level of Agreement Regarding the Challenges Related to Property Management of High-rise Residential Buildings

\begin{tabular}{|c|c|c|}
\hline & Issues & Average \\
Index & Rank \\
\hline To enforce and ensure all unit owners pay their maintenance fee. & 7.94 & 1 \\
\hline To collect monthly maintenance fee from the owners/residents. & 7.78 & 2 \\
\hline The appointed PM do not properly manage and maintain the property of HrRB. & 7.03 & 3 \\
\hline To lower the maintenance cost to encourage purchaser's participation in Property Management. & 6.72 & 4 \\
\hline $\begin{array}{c}\text { To respond to the user complaints through accurate media of communication and information in ensuring } \\
\text { every complaint from them is being heard and appropriate action taken within customer charter. }\end{array}$ & 6.69 & 5 \\
\hline $\begin{array}{c}\text { To provide and show case a satisfying result of property management and maintenance within the budget. } \\
\text { (Well managed and maintained). }\end{array}$ & 6.63 & 6 \\
\hline $\begin{array}{c}\text { Demand from owners that residential management needs to encompass a variety of services from cleaning } \\
\text { and security services to comprehensive maintenance. }\end{array}$ & 6.56 & 7 \\
\hline JMB offers negotiable discussion regarding the issue of a fee increase for PM. & 6.50 & 8 \\
\hline To clarify the legislation regarding the property management of HrRB to guide the management activities. & 6.44 & 9 \\
\hline To prepare good design-and-build inputs in the early stage to achieve excellent property management. & 6.41 & 10 \\
\hline To manage the tasks in the given time within optimum cost. & 6.38 & 11 \\
\hline To form effective communication between developers and appointed PM company/team. & 6.34 & 12 \\
\hline To propose a framework for a good and effective management system. & 6.34 & 13 \\
\hline To manage the PM staff hired on a contract basis versus permanent staff. & 6.16 & 14 \\
\hline To offer the best maintenance fee concept with sustainable management operation. & 5.97 & 15 \\
\hline
\end{tabular}


Table 2 shows the results of the agreement level among the respondents toward the challenges faced by the developers in relating to the property management of HrRB highlighted in the survey questionnaires. Fifteen issues have been raised in the questionnaires to discover how severe the issues are, from the developers' perspective. The table represented the level of agreement of the developers for each highlighted challenge in the questionnaire, and the highlighted challenges are arranged by ranking from the highest mean score to the lowest mean score. From the results, the three prominent issues identified by respondents are: To enforce and ensure that all unit owners pay their maintenance fee, To collect monthly maintenance fee from the owners/residents and To lower the maintenance cost to promote purchaser's participation in FM are seen as the most crucial challenges related to property management in high-rise building residential.

The maintenance fee is an amount of money collected by JMB / Management Corporation (MC) to maintain the building and all provided facilities. Maintenance works for damage recovery need to be carried out to ensure the building and provided facilities are in good condition. However, the lack of awareness amongst residents on the importance of maintenance fees leads to poor maintenance work done. It's almost impossible in most HrRB to achieve a hundred percent collection from the owners. Some owners are reluctant or intentionally refuse to pay the maintenance fee but still enjoy the provided facilities in the buildings. In some cases, they are amongst complainants that grumble about defects and maintenance issues even they always skip paying the monthly maintenance fee. As mentioned by (L.T. Tiun, 2009), good financial support will result in excellent property management services. Unfortunately, Malaysia can still be considered new through experience in managing $\mathrm{HrRB}$ where we are still inconsistent due to lack of maintenance funds (S.R.H Abd-Wahab, 2016; L.T. Tiun, 2009). Fee collection and arrears present the two most significant challenges for any management body (such as developer, local authority, management corporations and resident organizations) undertaking the management of strata housing scheme (R. Liass, 1998; K. Roerup, 1998; J. Hussain, 1994; KPKT, 1999; JPN, 2001; M.A. Razali, 2001; S. Ismail, 2003; L.T. Tiun, 2003; PKNS, 2004; Eddy, C. L. L., 2004). Therefore, to enforce and ensure that all unit owners pay their maintenance fee and to collect monthly maintenance fee from the owners/residents in the developer perspective are the most challenging task.

Another challenge in HrRB is the high cost of service maintenance. There are many factors that influence the high cost of maintenance services, such as building characteristics, human aspects, the way how to carry out maintenance, and government policies. B. Ihsan et al., (2018) identified and grouped some of the factors into seven (7) categories where engineering services, labor, building materials, environments, management and administration, budget and finance, and building users are included as the factors. This was confirmed by A.S. Ali et al., (2010) and N.Z. Che-Ghani et al., (2016) who found out that factors such as building materials, building services, building age, tenants expectation, failure to execute periodical maintenance, imperfect maintenance, long outstanding maintenance charges, political, over budgeting and some other factors contribute immensely to the high cost of maintenance. Another risk factor contributing to the high cost of maintenance and resulting financial losses is the results of poor design and construction practices, poor accessibility for maintenance, inappropriate materials selection, used of low specifications, discontinuity of product or spare parts, non-availability of tools and instruments for regular maintenance and environmental conditions (N. De Silva et al,. 2012). Proper maintenance practice will preserve the building's value and makes the property enjoyable and a pleasure to reside. In addition, proper building maintenance will result in minimal repair costs, minimize energy consumption, level up user satisfaction, increase activity efficiency and eliminate potential safety hazards (L Wijaya et al., 2020). Ignoring this proper maintenance will damage the building structure and eventually will lead to legal action taken by the resident (S Saharuddin et al., 2020). Another challenge of building maintenance is the minimal consideration or lack of input from the expert facilities managers who take oversight responsibility for damage recovery and maintenance management in the early design stages. Most of the building maintenance challenges can be minimised if the opinions or inputs of property management professionals are fully engaged on damage recovery and maintenance management techniques and operations for consideration during the early design stages (W. Anthony et al., 2010). Other relevant information provided by property managers to designers minimises design errors that lead to unsatisfactory results during the facilities maintenance operations phase (H.B. Jawdeh et al., 2010). It is necessary to adopt maintenance input in the design stages to ensure that opinions can be used as a reference for ease of maintenance in the future, to reduce design defect where poses challenges for maintenance (A.S Ali et al., 2013). According to O.J. Omotechinshe et al., (2015), the maintenance aspect is scarcely considered in most design processes, and maintenance professionals are rarely invited into the design teams. This often raises or leads to maintenance problems which badly affect the performance of such buildings.

\subsection{The Major Roles of Developer in Collaboration with Joint Management Body (JMB) to Manage the Properties in the High-Rise Residential Buildings (HrRB)}

Table 3 shows the result of the respondents' opinion on 
the major roles of the developer in JMB and the agreement percentages of respondents on the issues related to property management.

Table 3. The Level of Agreement Regarding the Roles of Developers in JMB in Property Management of High-rise Residential Buildings

\begin{tabular}{|l|c|c|}
\hline \multicolumn{1}{|c|}{ Collaboration Methods } & $\begin{array}{c}\text { Average } \\
\text { Index }\end{array}$ & Rank \\
\hline $\begin{array}{l}\text { Developer to provide high skills, education } \\
\text { and experiences requirements to their PM } \\
\text { organization. }\end{array}$ & 4.47 & 1 \\
\hline $\begin{array}{l}\text { Developer to promote and educate the } \\
\text { residents/owners on the rules, regulation } \\
\text { and good practice of stratified living ways. }\end{array}$ & 4.22 & 2 \\
\hline $\begin{array}{l}\text { Creates a win-win situation between } \\
\text { owners and management bodies by } \\
\text { introducing benefits that shall be gained by } \\
\text { practicing legitimate methods of property } \\
\text { management. }\end{array}$ & 4.22 & 3 \\
\hline $\begin{array}{l}\text { Coordinate training focusing on the work } \\
\text { process of management and maintenance } \\
\text { of properties in HrRB. }\end{array}$ & 4.13 & 4 \\
\hline $\begin{array}{l}\text { Developer to provide seminar/training on } \\
\text { property management related matters to } \\
\text { JMB. }\end{array}$ & 4.06 & 5 \\
\hline
\end{tabular}

As refer to Table 3 above, the result shows the Average Index is 4.47 , and almost $91 \%$ of respondents agreed that the Developer should provide high skills, education and experience requirements to their Property Management organization. This result indicates that the respondents agreed that the developers should play the major roles by providing high skills maintenance team, continuously educate the JMB with the knowledge about property management and share their experience in managing high-rise building residential with the JMB/MC so that they can achieve the effective property management.

The other issue that led to the damage recovery and maintenance management effectiveness was the lack of awareness amongst residents to involve in the organization's activities at their place (I.H. Fakhruddin, 2007; Y.C. Kuo et al., 2012; Y. Yau, 2011). As a developer, they should promote and educate their potential buyers/owners on the rules, regulations and good practice in stratified living ways. The developers should encourage their buyers/owners to attend any mutual activities organized by the management or resident's organization. Then, residents should take care of their common property that belongs to their place, such as a swimming pool, playground, gymnasium, etc. Furthermore, residents should not place their unused things in the public area such as corridor, staircase, and public area that will obstruct maintenance works (N.M. Tawil, 2009; I.H. Fakhruddin, 2007; Y.C. Kuo et al., 2012; Y. Yau, 2011). Therefore, awareness amongst residents to take care of their property is important to achieve damage recovery and maintenance management satisfaction at HrRB. Developers, Management Corporation, residents, and management agents must be cooperated to enhance the damage recovery and maintenance management efficiency at high-rise buildings. This can create a win-win situation between owners and management bodies by introducing benefits that shall be gained by practicing legitimate methods of property management.

\section{Conclusions}

Based on the survey, 32 respondents responded to the questionnaire. The respondents represented a broad spectrum of different professions, including architects, civil engineers, quantity surveyor, electrical engineers, mechanical engineer, quality manager and QAQC Engineer, project manager, project executive, assistant engineer and respectively from other professions, such as general manager, assistant manager, landscape architect, and M\&E supervisor. All of the respondents are working with Developer who had experienced in construction and development industries, starting from pre-planning, design, and construction up to the maintenance and operation stage. This shows that respondents are involved in construction and development thus, their opinion in this research is considering important.

Nowadays, high-rise building residential becoming more attractive with sophisticated design, fantastic façade, and more facilities provided by the developer to attract their buyer and add value to the development. However, all these attractive features will tag along with more complex issues and challenges during the operation and maintenance period. Therefore, the developer should forecast, anticipate and address the issues and challenges of maintaining this high-rise building at the initiating and design stage. This initiative will minimize operational and maintenance costs during the occupation period. Without proper planning during the design stage, the JMB / MC would face many issues in managing high-rise buildings and difficulty in resolving the same. If the issues are not being taken care of during the early stage, eventually, it will jeopardize the high-rise building system.

The influential roles performed by the developers are capable of creating efficient collaboration between members of JMB. From the developers' perspective, the roles include providing seminars and training related to the property management process to the appointed property management organization to produce a skillful, knowledgeable, and experienced management team. Next, education regarding the rules, regulations, and good practice of stratified living ways to the owners or residents would also be one of the developers' roles. Therefore, JMB members may have proper collaboration in managing the property of HrRB

From the developers' perspective, all suggested strategies are possible to be implemented for improving strata property management that enhances the effectiveness of damage recovery and maintenance of the common property. The strategies suggested are according 
to the challenges faced by the developers in managing the HrRB. Among the strategies are by setting out a program of fixed schedule for regular maintenance, make life easier for the owners by creating online complaint form, consider the future maintenance during preparing the project planning, provide training for the management team chosen and impose fines on owners for late payment of maintenance fee. Strata property management which involves JMB/ MC will improve into better services and systems in the near future. According to S.A.H. Syed et. Al., (2009), through more proactive campaigns will be able to change the thinking and perceptions of professionals involved in the construction and real estate markets. All the industrial players especially developer should play their important part by organizing special training and share their expertise to promote better and best practice in property management.

\section{Acknowledgments}

The authors would like to acknowledge Universiti Teknologi Malaysia for the financial support provided under UTMFR grant, Q.J130000.2551.21H52.

\section{REFERENCES}

[1] A. Tayyab, A. Aibinu, M.J. Thaheem. The Effects of High-rise Residential Construction on Sustainability of Housing Systems. Procedia Engineering, Vol. 180, 1695-1704, 2017.

[2] A.S. Ali, K.C. Keong, N. Zakaria, U. Zolkafli, F. Akashah. The Effect of Design on Maintenance for School Buildings in Penang, Malaysia. Structural Survey, Vol. 31 No. 3, 194-201, 2013.

[3] A.S. Ali, S.N. Kamaruzzaman, R. Sulaiman, C.P. Au-Yong. Factors Affecting Housing Maintenance Cost in Malaysia. Journal of Facilities Management, Vol. 8, No. 4, 285-298, 2010.

[4] A. Christudason. Common Property in Strata Titled Development in Singapore. Journal of Property Management, Vol. 22, No. 1, 14-28, 2004.

[5] B.G. Dale, Managing Quality (4th Ed.), Blackwell Publishing Ltd, Oxford, UK, 2003.

[6] B. Ihsan, A. Alshibani. Factors Affecting Operation and Maintenance Cost of Hotels. Property Management, 2018.

[7] C. C. Cui, B. R. Lewis, W. Park. Service Quality Measurement in the Banking Sector in South Korea. Journal of Bank Marketing, Vol. 21, No. 4, 191-201, 2003.

[8] D. Allen. What is building maintenance? Facilities, Vol. 11 No. 3, 7-12, 1993.

[9] Eddy, C. L. L. Challenges Facing Delivering Affordable Housing - Enhancing The Delivery System. Adequate Housing - A Human Right. 15 January 2004. Suruhanjaya
Hak Asasi Manusia Malaysia (SUHAKAM). Kuala Lumpur. Buletin REHDA Februari 2004. Selangor: Real Estate \& Housing Developers' Association Malaysia.

[10] F.U.M. Azian, N. Yusof, E.M. Kamal. Problems in high rise residential building: From management perspective; IOP Conf. Ser.: Earth Environ. Sci. 452 012087, 2020.

[11] H.B. Jawdeh, G. Wood, M.A. Abdul-Malak. Altering Design Decisions to Better Suit Facilities Management Processes. Proceedings of the Tenth International Conference for Enhanced Building Operations, Kuwait, October 26-28, 2010.

[12] I.H. Fakhruddin, M.Z. Suleiman, R. Talib. The Need to Implement Malaysia's Building and Common Property Act (Act 663) in Building Maintenance Management, Journal of Facilities Management, Vol. 9, 170-180, 2007.

[13] J.A. Al-khatam. Building Maintenance Cost. Unpublished Thesis (Msc), King Fahd University of Petroleum \& Minerals, Dhahran, Saudi Arabia, 2003.

[14] J. Bloemer, K. de Ruyter, M. Wetzels. Linking Perceived Service Quality and Service Loyalty: A Multi-Dimensional Perspective. Journal of Marketing, Vol. 33, No. 11/12, 1082-1106. MCB University Press, 1999.

[15] J. Hussain. Strata Title In Malaysia. Selangor: Pelanduk Publications (M) Sdn. Bhd, 1994.

[16] JPN. Towards Successful Housing Development in Malaysia. Bahagian Pembangunan \& Penyelidikan, Jabatan Perumahan Negara, RECENT ADVANCES in ENERGY \& ENVIRONMENT ISSN: 1790-5095 34 ISBN: 978-960-474-159-5 Malaysia. 2001.

[17] KPKT. Housing In The New Millenium - Malaysian Perspective, 1999. http://www.kpkt.gov.my/jabatan/jpn/artikel3.htm

[18] K. Roerup. Homeowners' Associations - A New Framework For Housing In Lithuania. Journal of Facilities, Vol. 16, No. 11, 302-305, 1998.

[19] L.T. Tiun. Pengurusan Kompleks Kediaman Tinggi: Gambaran \& Realiti. Kuala Lumpur: Utusan Publications \& Distributors Sdn. Bhd. RECENT ADVANCES in ENERGY \& ENVIRONMENT, 2003.

[20] L.T. Tiun. Pengurusan Kompleks Kediaman Tinggi: Gambaran \& Realiti. Kuala Lumpur: Utusan Publications \& Distributors Sdn. Bhd, 2003.

[21] L.T. Tiun. Managing High-Rise Residential Building In Malaysia: Where Are We? Persatuan Sains Sosial, Universiti Putra Malaysia. 2009.

[22] L. Wijaya, Y Latief, R.A. Machfudiyanto. Development of Preventive Maintenance Guidelines for Architectural Components on Government Building Based on Work Breakdown Structure. Civil Engineering and Architecture, Vol. 8, No. 3. pp. 312 - 319, 2020.DOI: 10.13189/cea.2020.080315.

[23] M.A. El-Haram, M.W. Horner. Factors affecting housing maintenance cost. Journal of Quality in maintenance Engineering, Vol. 8, No. 2, 115-123, 2002.

[24] M.A. Razali. Perumahan Awam Di Malaysia: Dasar \& Amalan. Kuala Lumpur: Utusan Publications \& 
Distributors Sdn. Bhd, 2001.

[25] N. De Silva, M. Ranasinghe, C.R. De Silva. Risk Factors Affecting Building Maintenance Under Tropical Conditions. Journal of Financial Management of Property and Construction, Vol. 17, No. 3, 235-252, 2012.

[26] N.M. Tawil, A. Ramly, M.N. Daud, A. I. Che-Ani, I.M.S. Usman, A. Zaharim. An Analysis of Influence Factor in Choosing High-Rise Residential in Kuala Lumpur, Malaysia, Proceeding of the 4th IASME/WSEAS International Conference on Energy and Environment (EE'09), 332-335, 2009.

[27] N.Z. Che-Ghani, N.E. Myeda, A.S. Ali. Operations and Maintenance Cost for Stratified Buildings: A Critical Review. MATEC Web of Conference, 2016.

[28] O.J. Ometehinshe, D.I. Dabara, J. Guymu. Design Inadequacies and the Maintenance of University Buildings in IIe-Ife, Nigeria. Journal of Environment and Science, Vol. 5, No. 2, 175-187, 2015.

[29] PKNS. Bil Perkhidmatan Penyelenggaraan: Konsep \& Perlaksanaannya. Edaran Kota Damansara. Selangor: PKNS, 2004.

[30] P. Loftabadi. High-rise Buildings and Environmental Factors. Renewable and Sustainable Energy Reviews, Vol. $38,285-295,2014$.

[31] R. Liias. Housing Stock: The Facilities For Future Development. Journal of Facilities, Vol. 16, No. 11, 288-294, 1998.

[32] S.A.H. Syed Mustapa, H. Adnan, K. Jusoff. Facility Management Challenges and Opportunities in the Malaysian Property Sector Journal of Sustainable Development, Vol. 1, No. 2, 2009.
[33] S. Ismail. Pengurusan Penyenggaraan Bangunan \& Kualiti Kehidupan Di Kondominium Di Malaysia. Seminar Pengurusan \& Penyenggaraan Bangunan Ke-2, 22-23 Disember 2003.

[34] S.R.H. Abd-Wahab, A.I. Che-Ani, A. Sairi, N.M. Tawil, S. M.Z Abd-Razak. Classification of High-Rise Residential Building Facilities: A Descriptive Survey on 170 Housing Scheme in Klang Valley. MATEC Web of Conference, 2016.

[35] S.R.H. Abd-Wahab, A. Sairi, A.I. Che-Ani, N.M. Tawil, S. Johar. Building maintenance issues. International Journal of Applied Engineering Research, Vol. 10, No. 6, 15759-15776, 2015.

[36] S. Saharuddin, N. Khalil, A.A. Saleh. Prioritising Criteria of Maintenance For Green Roof In High-Rise Residentials, ISSN: 1985-7527, 2020.

[37] V. Soebiyan, J.F. Bobby Saragih, M. Tedja. Study on high-rise building using wind energy at humid tropical climate, Chemical Engineering Transactions, Vol. 56, 241-246, 2017.

[38] W. Anthony, W. Chris, G. Rod. The Consideration of Maintenance Issues During The Design Process in The UK Public Sector. In: Egbu C. (Ed) Procs 26th Annual ARCOM Conference, 6-8 September 2010, Lead, UK, Association of Researchers in Construction Management, 1091-1100, 2010.

[39] Y.-C. Kuo, J.-S. Chou. Enhancement of Condominium Management Based on the Effect of Quality Attributes on Satisfaction Improvement, Expert Systems with Applications, 39: 5418-5425, 2012.

[40] Y. Yau. Homeowners' Participation in Management of Multi-Storey Residential Buildings, Journal of Property Management, Vol. 29, 345-356, 2011. 